\title{
Gender, Need-Achievement and Assertiveness as Factors of Conceptions about Math among Secondary School Students in Ogun State, Nigeria
}

\author{
S. E. Oladipo ${ }^{1}$, A. A. Arigbabu ${ }^{2} \&$ Rufai Kazeem ${ }^{3}$ \\ ${ }^{1}$ Department of Counselling Psychology, College of Applied Education and Vocational Technology, Tai Solarin \\ University of Education, Ijagun, Ogun State, Nigeria \\ ${ }^{2}$ College of Science and Information Technology, Tai Solarin University of Education, Ijagun, Ogun State, \\ Nigeria \\ ${ }^{3}$ Department of Computer Science, College of Science and Information Technology, Tai Solarin University of \\ Education, Ijagun, Ogun State, Nigeria \\ Correspondence: S. E. Oladipo, Department of Counselling Psychology, College of Applied Education and \\ Vocational Technology, Tai Solarin University of Education, Ijagun, Ijebu Ode, Ogun State, Nigeria. Tel: \\ 234-80-3330-5472. E-mail: kingola2001@yahoo.com
}

Received: May 31, 2012 Accepted: August 3, 2012 Online Published: August 20, 2012

doi:10.5539/res.v4n4p141 URL: http://dx.doi.org/10.5539/res.v4n4p141

\begin{abstract}
This study investigated the influence of Gender, need-achievement and assertiveness on conceptions about math among senior secondary school students in Ijebu-Ode Local government area of Ogun state. Using an ex-post facto survey research design and multiple sampling methods, a total of 350 participants participated in the study. 127 (36.3\%) were male, $223(63.7 \%)$ were female. $150(42.9 \%)$ were from female only schools, $150(42.9 \%)$ were from co-educational schools and 50 (14.3\%) from male only schools. Validated scale was used for data collection. The two hypotheses stated were rejected based on statistical insignificance. There was no significant relationship among gender, need achievement, assertiveness and conceptions. It thus follows that there are other variables, (apart from the ones that were considered in this study) that significantly influence conceptions about mathematics among secondary school students. Attention should therefore be focused on further studies in this area, in order to be able to pigeon-hole the factors that may account for the different conceptions about math, so that right measures will be applied to help students change the wrong conceptions and be better in mathematics as a school subject.
\end{abstract}

Keywords: assertiveness, need-achievement, conceptions, senior secondary school

\section{Introduction}

Mathematics in school is the foundation for later learning at the university level (Crawford, Gordon, Nicholas, \& Prosser, 2006). Research at the school level indicates that the learners' previous experiences influence the quality of their approaches to learning, attitudes to and outcomes in learning mathematics (Crawford, 1990). There are indications that students' conceptions of mathematics and their orientations to study affect the purity of cognitive activity and of learning outcomes (Kloosterman, 2002). Studies such as Bell (1993), Canobi (2005), Hiebert and Carpenter (1992), Mason and Spence (1999) and Yager (1991) showed that students' conceptions of understanding mathematics are important in their success in mathematics. Also, the ways in which learners interpret the context of their mathematical learning and hence the ways they relate to mathematical activities influence their mathematical thinking (Crawford, 1990).

Researchers have identified that variables that can account for different perceptions about mathematics could be learner factors Canobi (2005), teacher factors; or environmental factors. For examples, in the introduction to the UNESCO publication, "Significant influences on children's learning of mathematics" Bishop, Hart, Lerman, \& Nunes (1993) established that the learning of mathematics is not free from cultural and societal influences. For the purpose of this study, we are focusing on learner factors that can account for their views about mathematics; attention is therefore focused on students' Conceptions about mathematics as it is influenced by their gender, level of assertiveness and need achievement. 
Gender here refers to the categorization of people based on their sex as either male or female and at different times and places; it has been observed that several stereotypical and biased assumptions have been made when using gender for categorizations. For example, males are considered to be more logical than females (Sumpter, 2008), mathematics is considered a male dominated course. It is in this context that boys and girls develop their gender identities by facing, often contradictory, images and negotiate them to a personal identity (Volman\& Ten Dam, 1998). As stated earlier, many students in the senior secondary school perceive mathematics as a male domain (Brandell \& Staberg, 2008), which means that the structure, the symbols and the identity are all more likely to be pro-male. Such an environment could be connected to a potential underperformance by women since they are under a stereotype threat (Cadinu et al., 2005). It is therefore necessary to find out (empirically) if gender actually influences secondary school students' conceptions about mathematics.

Need achievement motivation as defined by McLelland has to do with peoples' desire to achieve great feat in life. Such people seem to have an inner motivator that propels them towards achievement (despite odds and limitations). People with a high need for achievement (nAch) seek to excel and thus tend to avoid both low-risk and high-risk situations. Achievers avoid low-risk situations because the easily attained success is not a genuine achievement. In high-risk projects, achievers see the outcome as one of chance rather than one's own effort. High nAch individuals prefer work that has a moderate probability of success, ideally a $50 \%$ chance. Achievers need regular feedback in order to monitor the progress of their achievements. They prefer either to work alone or with other high achievers. It is hypothesized that students who are high on need achievement should also have positive conceptions about mathematics.

Assertiveness is the direct and honest communication of someone's opinions, feelings, needs, and rights in a way that does not violate the personal rights of others. It involves standing up for your own rights, while acknowledging the rights of others, and working towards a win-win solution. Assertiveness is different from non-assertiveness and aggressiveness. Non-assertiveness (or submissiveness) is when you allow others to violate your rights by regarding their needs, opinions and rights as more important than your own. This shows a lack of respect for your own needs and can lead to feelings of hurt, anxiety and anger.

Conceptions have been defined by Thompson (1992) as "conscious or subconscious beliefs, concepts, meanings, rules, mental images, and preferences". Conception is defined here as an abstract or general idea that may have both affective and cognitive dimensions, inferred or derived from specific instances. Hence, students' conceptions consist of their belief systems, values and attitudes reflecting their experiences. Beliefs are by the above definition part of conceptions. Sumpter (2008) defined beliefs as an individual's understandings that shape the ways thatindividual conceptualizes and engages in mathematical behaviour generating and appearing as thoughts in mind. A belief could be central and strongly held, or peripheral and likely to change. This dimension doesn't exist in a knowledge system (Furinghetti \& Pehkonen, 2002). If you know something, you are not likely to accept any contradiction to this. Beliefs are held in clusters. These clusters may not necessarily have any relationship with each other and thus could be kept isolated. The reasons for seeing beliefs as a part of a system is that beliefs are not isolated and they are context/ situation bound. They function in operational terms as a part of a model of cognition.

\subsection{Statement of Problem}

The observed research problem; which has necessitated the conduct of this study has been the lack of understanding of the students' conceptions of mathematics as a school subject; particularly with regard to the influence of such variables as gender, assertiveness and need achievement motivation. A lack of students' conception of math, can possibly give rise tostudents' ineffective learning and or teachers' incompetent teaching and the eventual compromising of the quality of students thus produced, who will be admitted into the tertiary institutions for further studies.

\subsection{Review of Related Literature}

There is a dearth in literature regarding conceptions about mathematics as it relate to need achievement and assertiveness, the few that are available treat gender mainly and attempt has been made as much as possible to glean the relevant literature; no matter how insufficient they may be.

Students seem to hold a variety of views of mathematics in the classroom (Khiat, 2010). Across the academic levels, elementary students see that effort, regardless of ability, is the key to learning mathematics, but when they advance to high school level; they see the lack of ability as a significant impediment in mathematics learning (Kloosterman \& Cougan, 1994). In the classroom, some students may believe that a good grade is important in mathematics assessment, while others may not (Hurn, 1985). Some students view mathematics learning as interesting, others may believe that it is a form of tedious and monotonous work (Cooney, 1992). Others may even see mathematics as a subject that causes them negative emotions such as fear, anxiety and anger during lesson 
(Hoyles, 1982). Some students feel that they learn mathematics because of their intrinsic interest in it (Kloosterman, 2002). At the same time, some students may view mathematics learning as being forced on them by schools and teachers (Ainley, Bills, \& Wilson, 2005; Cotton, 1993). These students may possibly feel that they do notunderstand the "purpose" of the mathematics tasks assigned to them and thus see no meaning in doing these exercises (Ainley \& Pratt, 2002). Students may also feel that some of the so called real world contexts used by teachers to relate to mathematics concepts may not be interesting to them and even create confusion in their problem solving (Ainley, 2000; Silverman, Winograd, \& Strohauer, 1992). In terms of learning mathematics effectively, Kloosterman, (2002) reported that students view procedures as more important than concepts. They also feel that memorisation is an important part of mathematics learning (Kloosterman, 2002). In relation to social influences in mathematics learning, some students may believe that teachers make learning mathematics difficult to understand and give little guidance to their mathematics learning (Kloosterman, 2002). On the other hand, other students may view mathematics as a subject where failure to achieve the right answers is usually met with disapproval and criticism by their teachers (Ernest, 2004). At the same time, some students may recognize that peers can help or impede them in their mathematics learning (Zimmer \& Toma, 2000). The various studies above showed that students can hold a huge diversity of views about mathematics learning at personal, social, conceptual, procedural, cognitive and emotional levels. Such views might possibly influence how well they are able to do mathematics.

Rittle Johnson et al. (2001) believed that a student's acquisition of conceptual understanding in mathematics can influence their level of acquisition of mathematical understanding at procedural level, or vice versa. On the other hand, Canobi (2005) also reported there is a relationship between the students' conceptual understanding of mathematics and their perceived proficiency of related mathematical procedures in problem solving. According to Vincent and Stacey (2008), having procedural competency in mathematics learning does not help to enhance conceptual understanding in learning mathematics. Kieran (1992) reported that students who failed to understand a mathematics formula conceptually would rely on memorising the procedures and thus could not see the essence of that formula.

In mathematics, gender-stereotyping is often favouring male despite equal performance in reality (Kimball, 1994, 1995; Walkerdine, 1998; Ohrn, 2002). There is evidence that a view of mathematics as a male domain exists among students at upper secondary and that positive motivational beliefs such as mathematics being joyful and a subject that will be needed for the future are considered male. Boys are thought of as successful in mathematics and therefore logical and clever. Girls are considered diligent and hardworking, but since they are seen to have to work more and harder than boys, they are therefore not as bright. Looking at upper secondary school teachers' attributions to students' mathematical reasoning, boys are assigned gender symbols such as multiple strategies (especially on the calculator), chance-taking and exploring (Sumpter, 2009). Gender differences in self-evalutationfavour males (Jackson et al., 1994). Male students have higher self-concepts, performance expectations and a positive intrinsic motivation (Skaalvik \& Skaalvik, 2004).

Researchers have established that assertiveness can help a student improvecommunication skills, self-esteem, and decision-making ability. It can help to overcome shyness and anger. Feelings and ideas can be expressed in an honest way, allowing relationships to become more genuine. The respect you show for other people can lead to others respecting you more. Assertiveness also gives you more control over your environment, reducing anxiety in difficult situations. Being assertive can lead to you having more time to study. All of these can positively impact a student's conceptions about and performance in mathematics as a school subject.

On the contrary, when a student behaves or interacts in a non-assertive manner, such a student allows his own needs to go unmet. There are many ways in which this could be detrimental to a student's academic life. One of the most common ways this occurs is when one allows other people to take up time that had set aside for study. For instance, if you have an assignment due the following day and your friends ask you to go out with them the night before, a person who was non-assertive might feel unable to say 'no', and would end up going out instead of doing the assignment. Another way non-assertiveness can affect one's academic life would be when one believes, correctly, that he deserved more marks for an assignment but take the non-assertive approach of doing nothing about it. This could make the difference between passing or failing the course overall. Finally, not asking for clarification of a point your lecturer has made and that you do not understand can also be considered non-assertiveness. This could mean you miss out on some information that is vital for the exam. All of these can affect a student negatively, particularly in the area of mathematics.

Based on the foregoing, the purpose of this study is to explore the influence of gender, need achievement and assertiveness on conceptions about mathematics, with a view to proffering solution to the problem of students' misconceptions about mathematics. It is also targeted at contributing to the available literature in the area of 
conceptions about mathematics and particularly as regards the variables of gender, need achievement and assertiveness. In the light of the purpose of this study, w hypothesized that:

1. Gender, Need achievement and Assertiveness will significantly positively correlate with Conceptions about Mathematics.

2. Boys will be significantly higher in their conceptions about mathematics than girls

\section{Method}

\subsection{Design}

This study adopts the ex-post facto survey research design. This was deemed suitable because the study went out to gather information that already existed among the population understudy and the researchers did not consciously or deliberately manipulate any of the variables of interest in the study.

\subsection{Population}

The target population for the study was the senior secondary school students within Ijebu Ode local government area of Ogun state. They were purposively selected from single sex schools as well as co-educational school. In other words, the population covered students in single sex schools (male and female) as well as co-educational schools (the mixed school where both male and female students are in the same school)

\subsection{Participants}

Participants in the study were 350 Senior Secondary School students drawn from 7 schools within Ijebu Ode local government area of Ogun state. Self-report measures were administered to collect data on the need achievement, assertiveness and conceptions about mathematics (which were the variables of interest in the study). Participation was voluntary and participants' anonymity was guaranteed.

\subsection{Sample and Sampling Procedure}

This research adopted the purposive sampling and random sampling methods for the selection of schools and participants respectively. Purposive sampling was adopted because, peculiar schools (with unique characteristics were used) spanning single sex schools (i.e. female only as well as male only) and co-educational schools (i.e. male and female). Participants were drawn from seven (7) schools, three (3) of the schools are co-educational, three (3) are girls-only school, while one (1) is boys-only school. Fifty (50) participants were randomly selected from the senior classes from each of these schools; giving a total of 350 participants that participated in the study.

\subsection{Instrument}

Validated scales were used for data collection. Conceptions about mathematics scale developed by Crawford, Gordon, Nicholas and Prosser (1998) was used to measure students' conception about mathematics. It is a 19-Item, 5 -point Likert format rating scale ranging from $1=$ Strongly Disagree through $5=$ Strongly Agree. The composite score on the scale is used for this study and a mean score and above indicates high conception about mathematics, while a score below the mean indicates a low conception about mathematics. The Alpha reliability co-efficient of .80 was recorded for this study.

Gender was measured as a demographic variable, hence participants only needed to indicate whether they were male or female, in section ' $A$ ' of the questionnaire.

Assertiveness was measured with the use of (Rathus, 1973). 8-item assertiveness schedule (RAS) which has a test-retest reliability of (0.77) and high validity of (0.93), as reported by the author; (Rathus, 1973). However, for the present study, the coefficient alpha of RAS is 0.62 . A mean score and above indicate that the individual is high on assertiveness, while a score below the mean indicates that the individual is low on assertiveness.

To measure Need achievement, Mc 9-item nAch was used. It is in the likert format and the responses ranged between strongly agreed - strongly disagree, some items are in the reversed order. For this study, an Alpha reliability of .76 was established. A score above the mean on the scale indicates a high need achievement, while a score below the mean indicates a low need achievement motivation.

\subsection{Procedure for Data Collection}

Permission was obtained from each of the principals of the schools from where the participants were drawn. On an agreed date, the researchers, with the support of research assistants went to each of the schools and administered the questionnaires with the assistance of the school teachers as well (particularly the math teachers). Since the average time of completion of the questionnaire is about ten minutes, the questionnaires were responded to and collected back the same day. In all, 350 properly filled questionnaires were retrieved and used for data analysis. 


\subsection{Method of Data Analysis}

The first hypothesis was analyzed using Pearson Product Moment correlation statistic, while the second hypothesis was analysed with the independent t-test.

\section{Results}

Table 1. Correlations matrix showing the relationship among the variables

\begin{tabular}{lccc}
\hline & Conceptions about math & Assertiveness & Need-achievement \\
\hline Assertiveness & .036 & & \\
Need-achievement & .067 & $.122^{*}$ & .013 \\
Gender & -.063 & -017 & \\
\hline
\end{tabular}

*. Correlation is significant at the 0.05 level (2-tailed)

The result of the general correlation analysis as shown in table 1 above shows that there is no significant relationship among the variables. It was only need-achievement that correlated significantly with assertiveness. With the result, as shown above, the first hypothesis is rejected since there is no significant relationship among the variables. A further analysis was conducted to split the variables and look at how male and female fared on the variables. The split revealed that, the observed significant relationship that existed between assertiveness and need achievement was even accounted for among females and not males; this is shown in table 3 .

Table 2. Correlations matrix showing the relationship among the variables when looking at male students alone

\begin{tabular}{lcc}
\hline & conceptions about math & Assertiveness \\
\hline Assertiveness & -.073 & \\
Need-achievement & .060 & .055 \\
\hline
\end{tabular}

*. Correlation is significant at the 0.05 level (2-tailed)

Table 2 shows the result of correlation done after splitting the data, based on gender (i.e. male/female) in order to find out whether it was males or females that account for the relationship. Table 2 showed that there is no significant relationship between need achievement and assertiveness among male students.

Table 3. Correlations matrix showing the relationship among the variables when looking at female students alone

\begin{tabular}{lcc}
\hline & conceptions about math & Assertiveness \\
\hline Assertiveness & .109 & $.171^{*}$ \\
Need-achievement & .075 & .075
\end{tabular}

*. Correlation is significant at the 0.05 level (2-tailed).

Table 3 shows the result of correlation done after splitting the data based on gender (i.e. male/female) in order to find out whether it was males or females that account for the relationship. Table 3 showed that the significant relationship between need achievement and assertiveness is actually observed among female students.

Table 4. Summary of t-test of independent samples showing the difference between male and female students on conceptions about mathematics

\begin{tabular}{|c|c|c|c|c|c|c|c|c|}
\hline \multicolumn{9}{|c|}{ Group Statistics } \\
\hline & Gender & $\mathrm{N}$ & Mean & Std. Deviation & Std. Error Mean & Df & $\mathrm{t}$ & $P$ \\
\hline Conceptions & Male & 127 & 47.00 & 12.768 & 1.133 & 348 & 1.70 & $>.05$ \\
\hline about Math & Female & 223 & 45.46 & 11.255 & .754 & & & \\
\hline
\end{tabular}

*. Correlation is significant at the 0.05 level (2-tailed).

The result of t-test analysis as shown in table 4 above shows that gender is not a significant predictor of conceptions about mathematics, among Senior Secondary School students. This thus means that the second 
hypothesis is rejected. This sounds somehow revealing since there seems to be a general assumption that boys most probably would do better and have better conceptions about mathematics as compared with girls.

\section{Discussion}

The present study set out to examine the influence of gender, need achievement and assertiveness on conceptions about mathematics among Senior Secondary School students in Ijebu Ode local government of Ogun state. It was hypothesized that:

(1) Gender, Need achievement and Assertiveness will significantly positively correlate with Conceptions about Mathematics.

(2) Boys will be significantly higher in their conceptions about mathematics than girls. The result data analysis done did not however confirm any of these hypotheses.

Although researchers have established that there is a relationship between gender and mathematics belief, our finding is at variance with this. We also found out that there is no significant relationship between need achievement, assertiveness and conceptions about math. However, there was a significant relationship between assertiveness and need achievement. Interestingly, when a split analysis was done, based on gender, it was discovered that the relationship even existed among female participants and not among male. i.e. it was within female participants that there was a relationship between need achievement and assertiveness. Although the focus of this study is not on need achievement and assertiveness per se, it is worth mentioning that there is a positive change among secondary school girls as it pertains to math as a school subject. What it thus means is that, the more assertive a girl is, the higher her need for achievement and the more likely she is to have a better conception about mathematics.

This study has established that there is no significant difference between the conceptions about math among boys and girls. This finding is contrary to previous findings of Jackson et al. (1994); Skaalvik and Skaalvik (2004); Kimball (1994, 1995); Walkerdine (1998) and Ohrn (2002) who have established that boys are better in math compared with girls and that there are significant differences in their levels of perceptions about math. The explanation for this present finding could actually be accounted for by the awareness creation campaign about gender equality and better chance for the girl-child in Nigeria. It will not be out of place to say that it is actually having effect and there is a cognitive change among girls about mathematics as a school subject. It seems math is no longer seen as a boy subject and the stereotype is being done away with. This is a favourable development in the sense that, the possibility of having more ladies in the science related courses will be higher and in a very short-while, the issue of gender mainstreaming will be a thing of the past.

With the foregoing, it will not be out of place to conclude that there is no significant relationship among gender, need achievement, assertiveness and conceptions about mathematics among secondary school students in ijebu ode local government of Ogun state. Any observed difference at any point in time must have been accounted for by other variables or factors apart from the ones that were examined in this study. Further study can therefore be carried out to investigate the possible variables that may account for the differences in the conceptions about mathematics among secondary school students.

\section{References}

Ainley, J. (2000). Constructing purposeful mathematical activity in primary classrooms. In C. Tikly, \& A. Wolf (Eds.), Themaths we need now (pp. 138-153). London: Bedford Way Papers.

Ainley, J., \& Pratt, D. (2002). Purpose and utility in pedagogic task design. In A. Cockburn, \& E. Nardi (Eds.), Proceedings of the 26th Annual Conference of the International Group for the Psychology of Mathematics Education (Vol. 2, pp. 17-24). University of East Anglia, Norwich. ERIC.

Ainley, J., Bills, L., \& Wilson, K. (2005). Designing spreadsheet-based tasks for purposeful algebra. International Journal of Computers for Mathematical Learning, 10, 191-215.

Bell, A. (1993). Principles for the design of teaching. Educational Studies in Mathematics, 24(1), 5-34.

Brandell, G., \& Staberg, E. M. (2008). Mathematics: a female, male or gender neutral domain? A study of attitudes among students at secondary level. Gender and Education, 20(5), 495-509.

Cadinu, M., Maass, A., Rosabianca, A., \& Kiesner, J. (2005). Why Do Women Underperform Under Stereotype Threat? Evidence for the Role of Negative Thinking. Psychological Science, 16(7), 572-578.

Canobi, K. H. (2005). Children's profiles of addition and subtraction understanding. Journal of Experimental Child Psychology, 92, 220-246. 
Crawford, K. (1990). School Definitions of Work: Their Impact on the Use of Technology in Mathematics Education. Proceedings of the Conference on the Political Dimensions of Mathematics Education. London Institute of Education.

Crawford, K. (1992). Cultural Processes and Learning: Expectations, Actions and Outcomes. International Congress on Mathematics Education. Quebec.

Crawford, K., Gordon, S., Nicholas, J., \& Prosser, M. (1994). Conceptions of Mathematics and how it is learned: The perspectives of students entering University. Learning and Instruction, 4, 331-345.

Crawford, K., Gordon, S., Nicholas, J., \& Prosser, M. (1998). University mathematics students' conceptions of Mathematics. Studies in Higher Education, 23, 87-94.

Crawford, K., Gordon, S., Nicholas, J., \& Prosser, M. (2006). Learning Mathematics at University Level: Initial Conceptions of Mathematics. The University of Sydney, NSW2006.

Hiebert, J., \& Carpenter, T. (1992). Learning and teaching with understanding. In D. Grouws (Ed.), Handbook of research on mathematics research and teaching (pp. 65-100). New York, NY: MacMillan.

Hoyles, C. (1982). The pupil's view of mathematics learning. Educational Studies in Mathematics, 13, 349-372.

Khiat, H. (2010). A Grounded Theory Approach: Conceptions of Understanding in Engineering Mathematics Learning. The Qualitative Report, 15(6), 1459-1488. Retrieved from http://www.nova.edu/ssss/QR/QR15-6/khiat.pdf

Kieran, C. (1992). The learning and teaching of school algebra. In D. A. Grouws (Ed.), Handbook of research on mathematics teaching and learning (pp. 390-419). New York, NY: Macmillan.

Kimball, M. M. (1994). Bara en mytattflickor "ars"amreimatematik. KvinnovetenskapligTidskrift, 15, 40-53.

Kimball, M. M. (1995). Feminist Visions of Gender Similarities and Differences. Harrington Park Press.

Kloosterman, P. (2002). Beliefs about mathematics and mathematics learning in secondary school. In G. Lerder, E. Pehkonen, \& G. Torner (Eds.), Beliefs: A hidden variable in mathematics education? (pp. 247-270). Netherlands: Kluwer Academic Publishers.

Mason, J., \& Spence, M. (1999). Beyond mere knowledge of mathematics: The importance of knowing-to act in the moment. Educational Studies in Mathematics, 38(3), 135-161.

Silverman, F. L., Winograd, K., \& Strohauer, D. (1992). Student generated story problems. Arithmetic Teacher, $39(8), 6-12$.

Sumpter, L. (2008). A reason to believe: beliefs as an influence on students task solving. Research reports in Mathematics Education 2, Department of Mathematics and Mathematical Statistics, Umea University.

Thompson, A. G. (1992). Teachers' beliefs and conceptions: A synthesis of the research. In D. A. Grouws (Ed.), Handbook of research on mathematics teaching and learning (pp. 127-146).

Vincent, J., \& Stacey, K. (2008). Do mathematics textbooks cultivate shallow teaching? Applying the TIMSS video study criteria to Australian eighth-grade mathematics textbooks. Mathematics Education Research Journal, 20(1), 81-106.

Volman, M. \& Ten Dam, G. (1998). Equal but different: contradictions in the development of gender identity in the 1990s. British Journal of Sociology of Education, 19(4), 529-545.

Walkerdine, V. (1998). Counting Girls Out. Falmer Press.

Yager, R. (1991). The constructivist learning model, towards real reform in science education. The Science Teacher, 58(6), 52-57.

Zimmer, R. W., \& Toma, E. F. (2000). Peer effects in private and public schools across countries. Journal of Policy Analysis and Management, 19(1), 75-92. 